\title{
Efecto de la raza paterna en características de la canal de corderos para carne en Hidalgo, México
}

\section{Effect of sire breed on carcass traits of meat lambs in Hidalgo, México}

\author{
María Monserrat López-Velázqueza, Lino de la Cruz-Colínb, J osé Armando Partida de la \\ Peñac, Glafiro Torres-Hernándeza, Carlos Miguel Becerril-Péreza , Germán Buendía \\ Rodríguezc, María del Rosario Jiménez Badillod, Rosa Hayde Alfaro Rodrígueze, \\ Rubén Darío Martínez-Rojerof, J osé Alfonso Hinojosa-Cuéllarg
}

\begin{abstract}
RESUMEN
El objetivo del estudio fue evaluar los efectos de la raza paterna (Charollais, Dorset y Texel), utilizando ovejas Hampshire, sexo y tipo de nacimiento de la cría, en características de la canal de los corderos. Después del destete

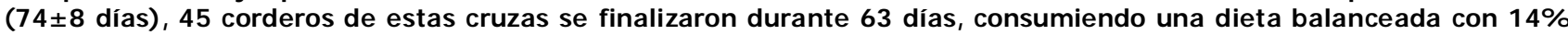
de PC y 2.82 Mcal de EM/ kg de MS. Los corderos se pesaron y se sacrificaron a los 137 días de edad; posteriormente, se tomaron medidas de peso y rendimiento de la canal caliente y fría, área del ojo de chuleta, espesor de grasa subcutánea, longitud de canal, longitud de pierna, perímetro de grupa y se calculó el índice de compacidad de la canal; además se determinó la composición regional de la canal (espaldilla, bajos, badal, pierna, cuello, y costillar). Los datos se analizaron utilizando un modelo mixto. Los corderos de padre Charollais tuvieron el mayor $(\mathrm{P}<0.05)$ área del ojo de chuleta $\left(20.1 \pm 0.5 \mathrm{~cm}^{2}\right)$, mientras que los de padre Dorset fueron superiores $(P<0.05)$ en longitud interna de la canal $(66.3 \pm 0.9 \mathrm{~cm})$ y longitud de pierna $(34.8 \pm 0.3 \mathrm{~cm})$. Los machos superaron a las hembras $(P<0.05)$ en la mayoría de las variables analizadas. Los corderos de parto sencillo tuvieron medias mayores que los de parto doble $(P<0.05)$ en espesor de la grasa subcutánea y longitud de la pierna. En general, las cruzas con Charollais y Dorset mostraron superioridad en las características de la canal.
\end{abstract}

PALABRAS CLAVE: Ovinos de carne, Razas paternas, Cruzamientos, Características de la canal, Composición regional.

\begin{abstract}
The objective of the study was to evaluate the effects of sire breed (Charollais, Dorset and Texel), utilizing Hampshire ewes, lamb sex and birth type, on carcass traits of the lambs. After weaning (74 8 d), 45 lambs from these crosses were fattened during $63 \mathrm{~d}$, consuming a balanced diet with $14 \% \mathrm{CP}$ and $2.82 \mathrm{Mcal}$ of ME/ kg of DM. Lambs were weighed and slaughtered at $137 \mathrm{~d}$ of age; later, measures on slaughter weight and yield of hot and cold carcass, rib eye area, subcutaneous fat, carcass length, leg length, and rump perimeter were taken and the carcass compactness index was calculated. In addition, the carcass regional composition (shoulder, chest-belly, anterior-loin, leg, neck, and rear-loin) was determined. Data were analyzed utilizing a mixed model. Charollais-sired lambs had the highest $(P<0.05)$ rib eye area $\left(20.1 \pm 0.5 \mathrm{~cm}^{2}\right)$, while Dorset-sired lambs were superior $(P<0.05)$ in carcass length $(66.3 \pm 0.9$ $\mathrm{cm})$ and leg length $(34.8 \pm 0.3 \mathrm{~cm})$. Ram lambs surpassed ewe lambs $(P<0.05)$ in most traits analyzed. Lambs born as singles had higher means than twin lambs $(P<0.05)$ in subcutaneous fat and leg length. In general, crosses with Charollais and Dorset showed superiority in carcass traits.
\end{abstract}

KEY WORDS: Meat sheep, Paternal breeds, Crossbreeding, Carcass traits, Regional composition.

\footnotetext{
Recibido el 27 de mayo de 2015. Aceptado el 29 de junio de 2015.

a Colegio de Postgraduados-Campus Montecillo. 56230 Montecillo, Edo. de México. Tel/Fax: 595-9520279. glatohe@colpos.mx. Correspondencia al cuarto autor. INIFAP-Hidalgo, Pachuca, Hgo. México. 


\section{INTRODUCCIÓN}

Actualmente, la prioridad de los sistemas de producción ovina en México es cubrir la demanda de carne en el mercado nacional, sobre todo para la elaboración de platillos tradicionales como la barbacoa (95\%), de la que su consumo per cápita rebasa ligeramente los 1,000 $\mathrm{g}^{(1)}$, a pesar de que en los últimos años se ha incrementado la comercialización de otros productos ovinos, como borrego al pastor, al ataúd, cortes finos, y cordero lechal, como sustitutos de cabrito(2).

A pesar de la mejora que ha tenido la ovinocultura mexicana, que le permitió producir 57,980 t de carne en canal en 2013(1), todavía se mantiene un déficit de carne para abastecer el consumo interno que se cubre con importaciones, pues la producción nacional no es capaz de satisfacer la demanda en forma oportuna, eficiente, y con la calidad requerida. Esto ha despertado el interés de productores y criadores para obtener información de nuevas razas que han sido introducidas al país, especialmente sobre aspectos relacionados con el comportamiento productivo, su respuesta a la selección y al sistema de cruzamiento(3), por lo que surge la necesidad de hacer evaluaciones genéticas y seleccionar aquellas razas o cruzas que cubran las necesidades y expectativas de los productores, los criadores y del mercado nacional(4). En el estado de Hidalgo se han introducido razas ovinas exóticas y se ha evaluado su desempeño productivo mediante pruebas de comportamiento(5) y en cruzamientos simples para determinar el efecto de la raza paterna(6); sin embargo, no se han efectuado estudios orientados a evaluar las características de la canal de importancia económica, ni se han evaluado las mejores estrategias de cruzamientos para utilizar esas razas en las principales regiones productoras del Estado.

Por lo anterior, el objetivo del estudio fue evaluar las razas Charollais, Dorset, y Texel como razas paternas, al ser apareadas con ovejas Hampshire, además del sexo y tipo de

\section{INTRODUCTION}

Currently, the priority of the sheep production systems in Mexico is to meet the demand of meat for the domestic market, especially for elaboration of traditional dishes such as barbecue (95\%), which consumption per capita slightly exceeds the $1,000 \mathrm{~g}^{(1)}$. This, despite increases in recent years of other sheep dishes, such as broiled lamb, coffin, steaks and lamb chops as a substitute for roasted $\mathrm{kid}(2)$.

Despite the improvement of the Mexican sheep industry, which enabled to produce $57,980 \mathrm{t}$ of meat carcass in $2013(1)$, there is still a deficit of meat to supply the domestic consumption, covered by imports, as national production is not sufficient to satisfy the demand in a timely, efficient manner, and with the required quality. This has aroused the interest of producers and breeders for information of new breeds that have been introduced to the country, especially on aspects related to productive performance, its response to selection and crossbreeding systems(3). Therefore, it is necessary to perform genetic evaluations and select breeds or crosses that meet the needs and expectations of producers, breeders, and the national market(4). Exotic breeds have been introduced in the State of Hidalgo and their productivity has been evaluated by performance tests and simple crosses(5) to assess the sire breed effect(6). However, it lacks studies for assessing the carcass traits of economic importance, and the best crossing strategies for these breeds have not been evaluated in the main regions of the State.

Therefore, the objective of the study was to evaluate Charollais, Dorset, and Texel sires, mated to Hampshire ewes; additionally to evaluate the sex and type of birth effects on carcass characteristics of lambs, in a commercial production system in Hidalgo, Mexico.

\section{MATERIAL AND METHODS}

The work was carried out on a private Ranch, located in the municipality of Cuautepec de 
nacimiento de la cría, en características de la canal de los corderos, en un sistema de producción comercial de Hidalgo, México.

\section{MATERIAL Y MÉTODOS}

El trabajo se realizó en un rancho particular ubicado en el Municipio de Cuautepec de Hinojosa, Estado de Hidalgo, a $20^{\circ} 5^{\prime} \mathrm{LN}$ y $98^{\circ}$ 17' LO y 2,261 msnm, un clima templado subhúmedo con lluvias en verano, una temperatura media anual de $15{ }^{\circ} \mathrm{C}$, y una precipitación pluvial de 600 a 1,100 mm/año(7).

Se utilizaron ovejas Hampshire con una condición corporal media (2.5, en escala de 1 a 5) de segundo parto, que se sometieron a un protocolo de sincronización de estros con esponjas intravaginales impregnadas con $20 \mathrm{mg}$ de acetato de fluorogestona. Se utilizaron 5 sementales Charollais, 2 Dorset y 3 Texel, que provenían de diferentes unidades de producción, seleccionados por su mejor comportamiento productivo. El empadre se llevó a cabo por monta controlada e inseminación artificial por vía intrauterina. Los machos permanecieron con las hembras durante 45 días, con el propósito de lograr el mayor número de hembras gestantes. De este empadre se obtuvieron 45 corderos de las cruzas Charollais $x$ Hampshire $(n=14)$, Dorset $x$ Hampshire $(n=15)$, y Texel $x$ Hampshire $(n=16)$. A los 12 días de nacidos se les aplicaron $0.2 \mathrm{ml}$ de selenio + vitamina $\mathrm{E}$ y se les ligó la cola. De los 15 a 45 días de edad los corderos recibieron un suplemento alimenticio (creep-feeding) a base de pellets con $18 \%$ de proteína cruda (PC). De los 45 días de edad hasta el destete (74 \pm 8 días) se les proporcionó heno de alfalfa, avena y una dieta balanceada con $15 \%$ de PC.

Después del destete los corderos se finalizaron en confinamiento durante 63 días. Al entrar a la etapa de la finalización los pesos iniciales de los tres grupos de corderos fueron $25.5 \pm 1.4$ $\mathrm{kg}$ (Charollais $x$ Hampshire), $26.4 \pm 1.1 \mathrm{~kg}$ (Dorset x Hampshire) y $26.5 \pm 1.1 \mathrm{~kg}$ (Texel $\mathrm{x}$ Hampshire). En esta fase los corderos recibieron
Hinojosa, State of Hidalgo, $20^{\circ} 5^{\prime} \mathrm{N}$ and $98^{\circ}$ $17^{\prime} \mathrm{W}$ at an altitude of $2,261 \mathrm{~m}$, in a temperate subhumid climate with rains in summer, an average annual temperature of $15{ }^{\circ} \mathrm{C}$ and a rainfall of 600 to $1,100 \mathrm{~mm}$ per year(7).

Hampshire ewes with an average body condition (2.5 on a scale of 1 to 5) and second parity, who underwent a protocol for estrus synchronization with intravaginal sponges impregnated with $20 \mathrm{mg}$ of fluorogestone acetate were used. The sires came from various production units, selected by their best productive performance, 5 Charollais sires, 2 Dorset and 3 Texel. Controlled mating and intrauterine artificial insemination was performed to breed the ewes. Males remained with the females for $45 \mathrm{~d}$, to achieve the highest number of pregnant ewes. This mating produced 45 crossbred lambs: Charollais $x$ Hampshire $(n=14)$, Dorset $x$ Hampshire $(n=15)$, and Texel $x$ Hampshire $(n=16)$. At $12 \mathrm{~d}$ after birth lambs were injected with $0.2 \mathrm{ml}$ of selenium + vitamin $\mathrm{E}$ and tail linked. At 15 to $45 \mathrm{~d}$ of age the lambs received a nutritional supplement (creep-feeding)-based pellets with $18 \%$ crude protein (CP). From $45 \mathrm{~d}$ of age until weaning (74 $\pm 8 \mathrm{~d}$ ) they were provided with alfalfa hay, oats and a balanced diet with $15 \%$ of CP.

After weaning, lambs were finished in confinement for $63 \mathrm{~d}$. Upon entering this stage of completion, initial weights of the three groups of lambs were $25.5 \pm 1.4 \mathrm{~kg}$ (Charollais $x$ Hampshire), $26.4 \pm 1.1 \mathrm{~kg}$ (Dorset $x$ Hampshire $\mathrm{x}$ ) and $26.5 \pm 1.1 \mathrm{~kg}$ (Texel $\mathrm{x}$ Hampshire). In this phase lambs received a balanced diet with $14 \% \mathrm{CP}$ and $2.82 \mathrm{ME} / \mathrm{kg}$ Mcal of DM, with $2 \%$ alfalfa, $8 \%$ of barley grain, $10 \%$ rolling corn and $80 \%$ concentrate feed. Later, the lambs moved to a TIF abattoir where they remained $24 \mathrm{~h}$ before slaughter, receiving the same feed throughout the period. Twelve hours before slaughter water and food were completely suspended. Later, procedures were those established by the federal authorities. Weight was recorded before the slaughter. 
una dieta balanceada con $14 \%$ de PC y 2.82 Mcal de EM/kg de MS, constituida con $2 \%$ de alfalfa, $8 \%$ de grano de cebada, $10 \%$ de maíz rolado y $80 \%$ de alimento concentrado. Posteriormente, los corderos se trasladaron a un rastro TIF en donde permanecieron $24 \mathrm{~h}$ antes de su sacrificio, recibiendo al llegar el mismo alimento que se les proporcionó en la finalización. Doce horas antes del sacrificio se suspendieron totalmente agua y alimento, y se realizó el faenado siguiendo los procedimientos establecidos por las autoridades federales. Antes de la matanza se registró el peso al sacrificio.

Una vez obtenida la canal, ésta se lavó y se llevó a la sala de oreo durante un periodo de $1 \mathrm{~h}$; pasado este tiempo se pesó la canal caliente y se refrigeró durante $24 \mathrm{~h}$ a $4{ }^{\circ} \mathrm{C}$, al término del cual se registró el peso de la canal fría y se obtuvo su rendimiento. Utilizando procedimientos de la literatura(8) se hizo la evaluación morfométrica de la canal, midiendo la longitud de la canal, longitud de la pierna, perímetro de la grupa, y se calculó el índice de compacidad de la canal, dividiendo el peso $(\mathrm{kg})$ entre la longitud $(\mathrm{cm})$. Posteriormente, se efectuó el despiece de la canal(8) y se registraron los pesos y porcentajes de los cortes primarios (espaldilla, bajos, badal, pierna, cuello, y costillar). Para determinar el área del ojo de la chuleta se hizo un corte transversal a la altura de la 13. a vertebra torácica, se dibujó el contorno del músculo en papel acetato y después se midió el área con un planímetro digital (PLanix 6, Tamaya Technics Inc., Tokio, Japón). El espesor de la grasa subcutánea se midió con una regleta graduada a la altura de la 13. a costilla, a $4 \mathrm{~cm}$ de la línea media dorsal.

Los datos obtenidos se analizaron con un modelo mixto mediante el procedimiento MIXED del paquete estadístico SAS(9), que incluyó raza paterna (Charollais, Dorset, y Texel), sexo del cordero (macho, hembra), y tipo de nacimiento del cordero (sencillo, doble) como efectos fijos, además del semental anidado dentro de raza paterna, como efecto aleatorio. En los análisis se incluyeron solamente las interacciones de
Once obtained, the carcass was washed and taken to the aerate room during a period of 1 $\mathrm{h}$; past this time the hot carcass weight was recorded and refrigerated for $24 \mathrm{~h}$ at $4{ }^{\circ} \mathrm{C}$ to register the cold carcass weight and its yield. The carcass morphometric evaluation was performed following procedures from the literature (8), by measuring carcass length, leg length, rump perimeter, and the carcass compactness index was calculated, dividing the weight $(\mathrm{kg})$ by the length $(\mathrm{cm})$. Subsequently, it was the cutting of the carcass(8); where carcasses were dissected to weigh and record percentages of the primary cuts (shoulder, chestbelly, anterior-loin, leg, neck, and rear-loin). The rib eye area was determined by a cross-section at the height of the 13th thoracic vertebra, the muscle contour was drawn in a paper acetate and the area was then measured with a digital planimeter (PLanix 6, Tamaya Technics Inc., Tokyo, Japan). Subcutaneous fat thickness was measured with a graduated strip at the height of the 13th rib, $4 \mathrm{~cm}$ from the dorsal midline.

Data were analyzed with a mixed statistical model using the MIXED procedure of the SAS package(9), which included sire breed (Charollais, Dorset, and Texel), lamb sex (male, female), and type of birth of the lamb (single, twin) as fixed effects, in addition to the sire effect nested within sire breed, as a random effect. Analysis included only first-order interactions. In case of statistical significance $(P \leq 0.05)$, subclasses means were compared with the Tukey test(10).

\section{RESULTS AND DISCUSSION}

Weight and carcass yield

Table 1 shows the mean ( \pm standard deviation) of the variables analyzed and least squares means ( \pm standard error) of the subclasses. There was no difference $(P \geq 0.05)$ due to sire breed in most of the variables, but Charollaissired lambs showed a pretty big rib eye area $\left(20.1 \pm 0.5 \mathrm{~cm}^{2}\right)$, which was $8.1 \%$ higher than that of the Dorset-sired lambs and $14.2 \%$ higher than the Texel-sired lambs. This contrasts 
Cuadro 1. Medias de cuadrados mínimos (media \pm error estándar) de características de la canal, según raza paterna, sexo, y tipo de nacimiento del cordero

Table 1. Least-squares means (mean \pm standard error) of carcass traits, according to sire breed, lamb sex, and lamb birth type

\begin{tabular}{|c|c|c|c|c|c|c|c|c|}
\hline \multirow[b]{2}{*}{ Variable } & \multicolumn{3}{|c|}{ Sire breed } & \multicolumn{2}{|c|}{ Lamb sex } & \multicolumn{2}{|c|}{ Lamb birth type } & \multirow{2}{*}{$\begin{array}{l}\text { Overall } \\
\text { means* }\end{array}$} \\
\hline & Charollais & Dorset & Texel & Male & Female & Single & Twin & \\
\hline$n$ & 14 & 15 & 16 & 20 & 25 & 21 & 24 & \\
\hline SW, kg & $46.6 \pm 1.6^{a}$ & $48.5 \pm 1.6^{\mathrm{a}}$ & $45.8 \pm 1.6^{a}$ & $50.4 \pm 1.4^{a}$ & $43.5 \pm 1.2^{b}$ & $48.4 \pm 1.4^{a}$ & $45.5 \pm 1.3^{a}$ & $46.4 \pm 6.7$ \\
\hline $\mathrm{HCW}, \mathrm{kg}$ & $26.0 \pm 1.1^{\mathrm{a}}$ & $26.6 \pm 1.2^{\mathrm{a}}$ & $24.9 \pm 1.1^{\mathrm{a}}$ & $27.4 \pm 0.9^{a}$ & $24.4 \pm 0.8^{b}$ & $26.4 \pm 0.9^{a}$ & $25.3 \pm 0.8^{a}$ & $25.6 \pm 3.9$ \\
\hline CCW, $\mathrm{kg}$ & $25.3 \pm 1.1^{a}$ & $26.1 \pm 1.3^{a}$ & $24.4 \pm 1.3^{a}$ & $26.6 \pm 0.9 a$ & $23.9 \pm 0.9 b$ & $25.9 \pm 0.9 a$ & $24.6 \pm 0.9^{a}$ & $24.9 \pm 3.8$ \\
\hline $\mathrm{HCY}, \%$ & $55.8 \pm 0.6^{a}$ & $54.7 \pm 0.6^{a}$ & $54.7 \pm 0.6 \mathrm{a}$ & $54.3 \pm 0.5^{a}$ & $55.8 \pm 0.4^{b}$ & $54.8 \pm 0.5^{a}$ & $55.3 \pm 0.5^{a}$ & $55.1 \pm 2.7$ \\
\hline CCY, \% & $54.1 \pm 0.9^{a}$ & $53.2 \pm 1.1^{a}$ & $53.5 \pm 1.0^{a}$ & $52.7 \pm 0.7^{a}$ & $54.4 \pm 0.7^{b}$ & $53.6 \pm 0.7^{a}$ & $53.6 \pm 0.7^{a}$ & $53.7 \pm 2.9$ \\
\hline $\mathrm{REA}, \mathrm{cm}^{2}$ & $20.1 \pm 0.5^{a}$ & $18.6 \pm 0.5^{b}$ & $17.6 \pm 0.5^{b}$ & $19.4 \pm 0.5^{\mathrm{a}}$ & $18.2 \pm 0.4^{a}$ & $18.5 \pm 0.5^{a}$ & $19.1 \pm 0.4^{a}$ & $18.7 \pm 2.3$ \\
\hline $\mathrm{SF}, \mathrm{mm}$ & $5.3 \pm 0.5^{a}$ & $4.5 \pm 0.6^{a}$ & $6.0 \pm 0.6^{a}$ & $5.1 \pm 0.4^{a}$ & $5.4 \pm 0.4^{a}$ & $5.9 \pm 0.4^{a}$ & $4.7 \pm 0.4^{b}$ & $5.1 \pm 1.9$ \\
\hline
\end{tabular}

$\mathrm{SW}=$ slaughter weight, $\mathrm{HCW}=$ hot carcass weight, $\mathrm{CCW}=$ cold carcass weight, $\mathrm{HCY}=$ hot carcass yield, $\mathrm{CCY}=$ cold carcass yield, $\mathrm{REA}=$ rib eye area, $\mathrm{SF}=$ subcutaneous fat.

ab Different literals in the same row, within subclass, indicate differences $(P<0.05)$. *: \pm standard deviation.

primer orden. En los casos de significancia estadística $(P \leq 0.05)$, las medias de subclases se compararon con la prueba de Tukey(10).

\section{RESULTADOS Y DISCUSIÓN}

Peso y rendimiento de la canal

En el Cuadro 1 se muestran las medias generales ( \pm desviación estándar) de las variables analizadas y las medias de cuadrados mínimos ( \pm error estándar) de las subclases. No hubo diferencias $(P \geq 0.05)$ debidas a raza paterna en la mayor parte de las variables, pero sí se observó que los padres Charollais produjeron corderos con un área del ojo de chuleta bastante grande $\left(20.1 \pm 0.5 \mathrm{~cm}^{2}\right)$, la cual fue $8.1 \%$ mayor que la de los corderos de padre Dorset y $14.2 \%$ más grande que la de los de padre Texel. Lo anterior contrasta con los resultados de otros trabajos en los que no se detectaron diferencias entre genotipos cuando evaluaron cruzamientos terminales con sementales Charollais y Romanov(11), o Suffolk y Texel(12), y sólo coinciden parcialmente con los resultados de la evaluación del cruzamiento de ovejas Katahdin con sementales Suffolk, Texel, with results from other study, in which no differences were detected among genotypes, when they evaluated terminals crosses with Charollais and Romanov sires(11), or Suffolk and Texel sires(12). Partially agrees with results of the evaluation of the crossbreeding of Katahdin ewes with Suffolk, Texel, Charollais and Dorper sires, where there were only differences $(P \leq 0.05)$ between the offspring of Charollais and Texel sires(13). The rib eye area is one of the most important of the carcass performance variables, since it correlates positively with the total proportion of muscle in the carcass(14).

Males outperformed females $(P \leq 0.05)$ in slaughter weight (+ $15.9 \%$ ), hot carcass weight $(+12.3 \%)$ and cold carcass weight $(+11.3 \%)$, which coincides with the results from other authors $(15,16)$. The opposite occurred in the yield carcass, both hot and cold (Table 1), because the females had a yield $3 \%$ higher than males $(P \leq 0.05)$. This is consistent with other authors that assessed the effect of sex on terminal crosses $(15,17,18)$. It seems that females have an advantage due to the grater amount of fat in the carcass(16), as well as by the greater weight of the viscera, head and skin of the 
Charollais y Dorper, en donde únicamente hubo diferencias $(\mathrm{P} \leq 0.05)$ entre las crías de padres Charollais y Texel(13). El área del ojo de la chuleta es una de las variables más importantes en el rendimiento de la canal, ya que se correlaciona en forma positiva con la proporción total del músculo en la canal(14).

Los machos superaron a las hembras $(P \leq 0.05)$ en el peso al sacrificio $(+15.9 \%)$, el peso de la canal caliente $(+12.3 \%)$ y el peso de la canal fría $(+11.3 \%)$, lo que coincide con los resultados de otros autores(15,16), mientras que lo opuesto se observó en el rendimiento en canal, tanto caliente como fría (Cuadro 1), donde las hembras tuvieron un rendimiento $3 \%$ mayor que los machos ( $\mathrm{P} \leq 0.05)$, lo cual concuerda con otros autores que evaluaron el efecto del sexo en cruzamientos terminales $(15,17,18)$, ventaja que tienen las hembras debido a la mayor cantidad de grasa en la canal(16), así como por el mayor peso de las vísceras, la cabeza y la piel de los machos(18). El rendimiento en la canal es de gran utilidad porque indica la proporción del peso vivo que puede ser comercializada como producto final (carne, grasa y hueso), información que puede ser complementada con la evaluación de la composición tisular y regional de la canal. Por otro lado, la diferencia entre el peso de la canal caliente y de la canal fría proporciona una idea de la merma que existe por el oreo y enfriamiento de la canal.

En el rendimiento en canal caliente se detectaron interacciones $(P \leq 0.01)$ entre la raza paterna y el sexo del cordero, así como entre raza paterna y tipo de nacimiento. En la primera interacción (Figura 1) no se observaron diferencias entre los corderos machos $(P \geq 0.05)$, pero sí entre las hembras $(P \leq 0.01)$, en donde las hijas de padres Charollais superaron a las de padres Dorset y Texel, lo que por un lado podría explicarse debido al mayor rendimiento que tuvieron las hembras en la canal caliente, y por otro debido a la superioridad de los corderos (machos y hembras) hijos de padre Charollais sobre los hijos de padre Dorset y Texel en el área del ojo males(18). The carcass yield is useful because it indicates the proportion of live weight that markets as a final product (meat, fat and bone), information that complements with the evaluation of the regional and tissue carcass composition. On the other hand, the difference between hot carcass weight and cold carcass weight provides an insight of the waste that exists by airing and cooling procedures.

There were interactions in the hot carcass yield $(P \leq 0.01)$ between sire breed and sex of lamb, as well as sire breed and type of birth. In the first interaction (Figure 1), there were no differences among the male lambs; while among females the Charollais-sired ewe lambs outperformed $(P \leq 0.01)$ those from Dorset and Texel sires. First, this could be explained by the increased performance that females had on the hot carcass; secondly, because of the superiority of the lambs (males and females) from Charollais parent upon the lambs from Dorset and Texel sires in the rib eye area, which is associated with most of the carcass meat.

In another interaction (Figure 2), there were no differences $(P \geq 0.05)$ among the three groups

Figura 1. Efecto de la interacción raza paterna x sexo del cordero en rendimiento de la canal caliente

Figure 1. Effect of the interaction between paternal breed $x$ sex of lamb in hot carcass yield

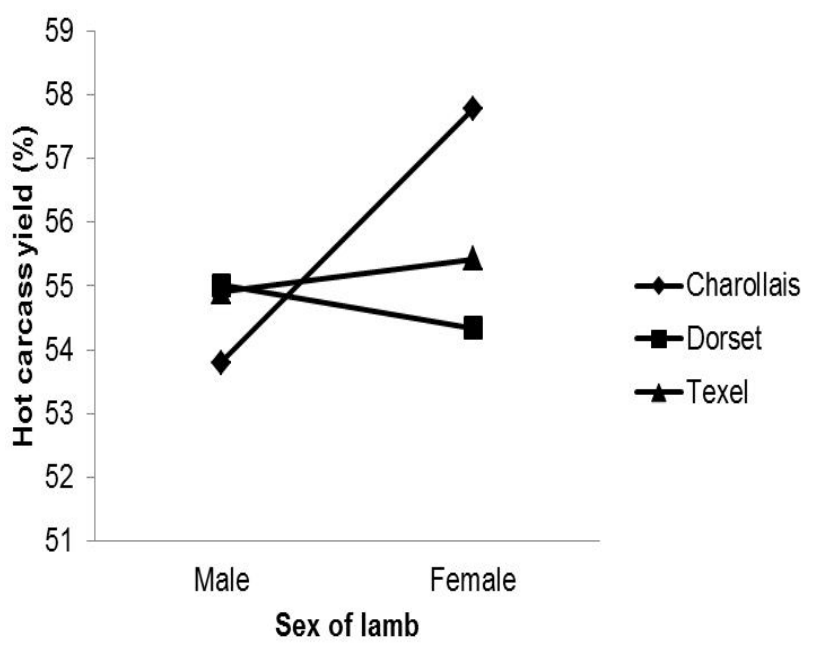


de la chuleta, que está asociada con mayor cantidad de carne en la canal.

En la otra interacción (Figura 2), no se observaron diferencias $(P \geq 0.05)$ entre los tres grupos de corderos nacidos de parto doble; sin embargo, entre los corderos nacidos de parto sencillo, los hijos de padres Charollais y Texel tuvieron medias mayores $(\mathrm{P}<0.01)$ que sus compañeros hijos de padres Dorset, efecto que posiblemente se debe a que, del total de corderos nacidos de parto simple, se observó que en su mayor parte fueron hembras, las que superaron a los machos en el rendimiento de la canal caliente y que, como ya se indicó, esta superioridad de las hembras se atribuye a la mayor cantidad de grasa que tienen en la canal(16), aunque en el presente trabajo ésta no se evaluó.

Asimismo, se observó un efecto $(P \leq 0.05)$ del tipo de nacimiento sobre el espesor de la grasa subcutánea, siendo los corderos de parto sencillo los que tuvieron un promedio mayor que los nacidos de parto doble. En parte, esto podría explicarse debido a que los corderos de parto sencillo son más pesados que los de parto doble

Figura 2. Efecto de la interacción raza paterna $x$ tipo de nacimiento del cordero en rendimiento de la canal caliente

Figure 2. Effect of the interaction between paternal breed $x$ type of birth of lamb in hot carcass yield

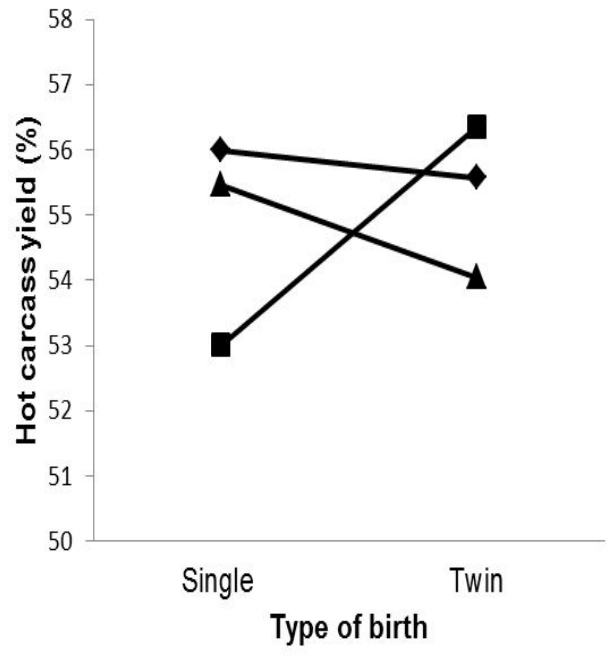

of twin lambs. However, among the single lambs, offspring from Charollais and Texel sires had higher means $(P<0.01)$ than Dorset-sired lambs. This could be explained because from the total single lambs, most were females, which outperformed males in hot carcass yield and, as already indicated, this superiority of females is attributed to the higher amount of fat in the carcass(16), although in this study that was not evaluated.

An effect of the type of birth on the thickness of subcutaneous fat was also found, singleborn lambs had a higher average than twin lambs $(P<0.05)$. In part, this could be explained as single-born lambs are heavier than twin lambs at an adult age(19). However, this effect appears to be non-definitive, since in other studies $(20,21)$ the type of birth had no influence on thickness of the subcutaneous fat. In addition, a sire breed by type of birth interaction effect $(P \leq 0.01)$ on the thickness of the subcutaneous fat was found (Figure 3). There was no difference $(P \geq 0.05)$ among the three groups of twin lambs. However, among the single-born lambs, Texelsired lambs had more subcutaneous fat than

Figura 3. Efecto de la interacción raza paterna $x$ tipo de nacimiento del cordero en espesor de la grasa subcutánea

Figure 3. Effect of the interaction between paternal breed $x$ type of birth of the lamb in the subcutaneous fat thickness

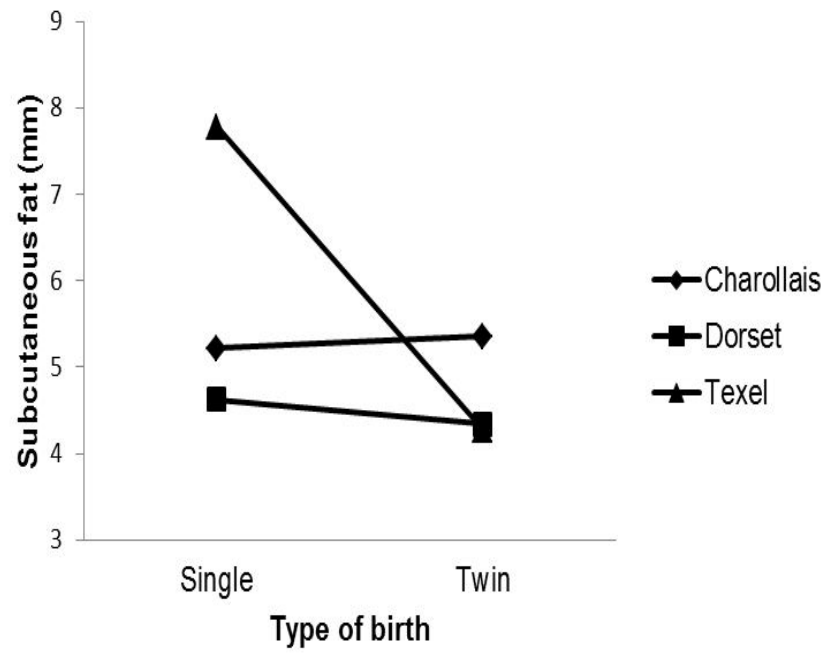


a edades adultas(19). Sin embargo, este efecto parece no ser definitivo, ya que en otros estudios $(20,21)$ el tipo de nacimiento no tuvo influencia en el espesor de la grasa subcutánea. Adicionalmente, se encontró una interacción $(P \leq 0.01)$ raza paterna por tipo de nacimiento en el espesor de la grasa subcutánea (Figura 3). No existieron diferencias $(P \geq 0.05)$ entre los tres grupos de corderos nacidos de parto doble; sin embargo, entre los corderos nacidos de parto sencillo, los hijos de padres Texel tuvieron mayor cantidad de grasa subcutánea que los hijos de padres Charollais y Dorset, lo que se puede explicar, aunque sólo parcialmente, por la superioridad que tuvieron los corderos nacidos de parto sencillo sobre los corderos nacidos de parto doble en esta característica (Cuadro 1).

Medidas morfométricas de la canal

En el Cuadro 2 se muestran las medias generales ( \pm desviación estándar) de las dimensiones de la canal y las medias de cuadrados mínimos ( \pm error estándar) de las subclases. Los corderos de padres Dorset tuvieron la mayor longitud de la canal y de la pierna. En un estudio(21) en el que se compararon diferentes genotipos se determinó que corderos Texel tuvieron promedios mayores $(P \leq 0.05)$ en la longitud de la canal que corderos Merino, Polwarth, Romney Marsh, y Corriedale, pero sin mostrar diferencias those from Charollais and Dorset sires, which can be explained, even if only partially, by the superiority that had the single-born lambs over the twin-born lambs in this trait (Table 1).

\section{Carcass morphometric measures}

Table 2 shows the overall mean ( \pm standard deviation) dimensions of the carcass and the least squares means ( \pm standard error) of the subclasses. Dorset-sired lambs had longer carcass and leg. A study that compared different genotypes (21) determined that Texel lambs had higher averages $(P \leq 0.05)$ in carcass length than Merino, Polwarth, Romney Marsh, and Corriedale lambs. Leg length was similar, which means a larger extension of the trunk, which could represent an advantage for the size of the loin, the cut with the highest carcass value. In contrast, another study(12) indicated that Texel lambs are characterized by having shorter carcass and leg length, but their carcasses are more compact than in the Suffolk lambs, which is attributed to the smaller size and precocity of the Texel breed in comparison to the Suffolk.

Males had longer carcass $(P \leq 0.01)$ and leg $(P \leq 0.05)$ length than females. In terms of the first variable, the results of this work are consistent with another study that evaluated Pelibuey lambs(22). However, differ from

Cuadro 2. Medias de cuadrados mínimos (media \pm error estándar) de medidas morfométricas de la canal, según raza paterna, sexo, y tipo de nacimiento del cordero

Table 2. Least-squares means (mean \pm standard error) of carcass morphometric measures, according to sire breed, lamb sex, and lamb birth type

\begin{tabular}{|c|c|c|c|c|c|c|c|c|}
\hline \multirow[t]{2}{*}{ Variable } & \multicolumn{3}{|c|}{ Sire breed } & \multicolumn{2}{|c|}{ Lamb sex } & \multicolumn{2}{|c|}{ Lamb birth type } & \multirow{2}{*}{$\begin{array}{l}\text { Overall } \\
\text { means }\end{array}$} \\
\hline & Charollais & Dorset & Texel & Male & Female & Single & Twin & \\
\hline$n$ & 14 & 15 & 16 & 20 & 25 & 21 & 24 & \\
\hline $\mathrm{CL}, \mathrm{cm}$ & $62.5 \pm 0.8 \mathrm{a}$ & $66.3 \pm 0.9 b$ & $61.2 \pm 0.9^{a}$ & $65.5 \pm 0.7^{a}$ & $61.2 \pm 0.6^{b}$ & $63.6 \pm 0.7^{a}$ & $63.0 \pm 0.6^{a}$ & $63.1 \pm 3.8$ \\
\hline $\mathrm{LL}, \mathrm{cm}$ & $33.4 \pm 0.3^{a}$ & $34.8 \pm 0.3^{b}$ & $33.2 \pm 0.3^{a}$ & $35.2 \pm 0.3^{a}$ & $32.3 \pm 0.3^{b}$ & $34.3 \pm 0.3^{a}$ & $33.3 \pm 0.3^{b}$ & $33.6 \pm 2.0$ \\
\hline $\mathrm{RP}, \mathrm{cm}$ & $67.0 \pm 1.1 \mathrm{a}$ & $68.2 \pm 1.4^{a}$ & $68.6 \pm 1.3^{a}$ & $67.9 \pm 0.9^{a}$ & $68.0 \pm 0.9 a$ & $68.3 \pm 0.9^{a}$ & $67.6 \pm 0.9^{a}$ & $67.8 \pm 3.5$ \\
\hline $\mathrm{CCl}$ & $0.4 \pm 0.01^{\mathrm{a}}$ & $0.4 \pm 0.02^{\mathrm{a}}$ & $0.4 \pm 0.02^{\mathrm{a}}$ & $0.4 \pm 0.01^{\mathrm{a}}$ & $0.4 \pm 0.01^{a}$ & $0.4 \pm 0.01^{a}$ & $0.4 \pm 0.01^{\mathrm{a}}$ & $0.4 \pm 0.05$ \\
\hline
\end{tabular}

$\mathrm{CL}=$ carcass length; $\mathrm{LL}=$ leg length; $\mathrm{RP}=$ rump perimeter; $\mathrm{CCl}=$ carcass compactness index.

ab Different literals in the same row, within subclass, indicate differences $(P<0.05)$. *: \pm standard deviation. 
en la longitud de la pierna, lo cual significa una mayor extensión del tronco que podría representar un ventaja para el tamaño del lomo, que es el corte de mayor valor en la canal. En contraste, otro estudio(12) indicó que los corderos Texel se caracterizan por tener menor longitud de la canal y la pierna, pero sus canales son más compactas que las de corderos Suffolk, lo cual se atribuye a la menor talla y mayor precocidad de la raza Texel en comparación con la Suffolk.

Los machos tuvieron mayor longitud de la canal $(P \leq 0.01)$ y de la pierna $(P \leq 0.05)$ que las hembras. En cuanto a la primera variable, los resultados coinciden con los de otro estudio en que se evaluaron corderos Pelibuey(22); sin embargo, difieren de las observaciones de otros autores que evaluaron cruzamientos terminales con sementales Dorset, Hampshire y Suffolk(15) o Suffolk y Merino Precoz(23), en las que el sexo no tuvo influencia o, incluso, las hembras hijas de padres Hampshire y Suffolk tuvieron mayor longitud de la canal $(\mathrm{P} \leq 0.05)$ que los machos(15). Con respecto a la extensión de la pierna, en estudios realizados con corderos de raza Canaria de lana y de pelo(24), al igual que en corderos de razas Churra Galega Bragançana y cruzados de Suffolk y Merino Precoz(23), no se detectaron diferencias en la longitud de la pierna debidas a sexo, posiblemente porque fueron sacrificados en una etapa temprana, en la que el porcentaje del peso maduro que habían alcanzado aún era bajo.

Con respecto al efecto del tipo de nacimiento sobre las dimensiones de la canal, sólo se observaron diferencias en la longitud de la pierna, siendo ligeramente más largas las piernas de los animales de parto simple $(P \leq 0.05)$, lo cual se explica parcialmente porque los corderos de nacimiento sencillo llegan a la edad adulta con mayor tamaño que los de nacimiento doble(18), lo que coincide con resultados de otros investigadores (25), quienes indicaron que los corderos de nacimiento sencillo tuvieron mayor longitud de la pierna desde que nacen, ventaja que conservan hasta que llegan observations from other authors that assessed terminal crosses with Dorset, Hampshire and Suffolk(15) or Suffolk and precocious Merino sheep(23), in which sex did not influence or, even, the females from Hampshire and Suffolk sires had longer carcasses $(P \leq 0.05)$ than the males(15). With regard to the extension of the leg, in studies with Canaria wool and hair sheep breed(24), and in lambs of Churra Galega Bragançana breeds and early Merino and Suffolk cross(23), no differences were detected in the leg length due to sex, possibly, because slaughter occurs at an early stage in which the percentage of mature weight reached was still low.

With respect to the effect of type of birth on the carcass dimensions, only the leg length shows differences, being slightly longer in singleborn lambs ( $P \leq 0.05)$, partially explained because single-born lambs reach adulthood with larger size than twin lambs(18). This agrees with results of other researchers(25), who indicated that single-born lambs had longer leg since they are born, an advantage that remains until they reach adult age(26). These same authors found that the type of birth affects the leg circumference, because Makuie I ranian lambs had higher values of this parameter $(\mathrm{P} \leq 0.05)$ in single-born lambs than in twins and triples. The importance of the leg size is because this piece is considered as a prime cut with a high economic value, which if it also has a wide circumference, it can improve the carcass quality, as the classification systems value better carcasses with rounded and convex leg profiles.

Regional composition of the carcass

Although some studies show a direct effect $(P \leq 0.05)$ of genotype on the regional carcass composition $(27,28)$, this work did not show such effect $(P \geq 0.05)$ due to sire breed, both in absolute and relative pieces of the carcass. Regarding the effect of sex, Tables 3 and 4 show that males outperformed females $(P \leq 0.05)$ in the weight and percentage of the shoulder and anterior-loin, but females had higher 
Cuadro 3. Medias de cuadrados mínimos (media \pm error estándar) de los pesos $(\mathrm{kg})$ de cortes primarios de la media canal izquierda, según raza paterna, sexo, y tipo de nacimiento del cordero

Table 3. Least-squares means (mean \pm standard error) of weights $(\mathrm{kg})$ of major cuts of the left half carcass, according to sire breed, lamb sex, and lamb birth type

\begin{tabular}{|c|c|c|c|c|c|c|c|c|}
\hline \multirow[t]{2}{*}{ Variable } & \multicolumn{3}{|c|}{ Sire breed } & \multicolumn{2}{|c|}{ Lamb sex } & \multicolumn{2}{|c|}{ Lamb birth type } & \multirow{2}{*}{$\begin{array}{l}\text { Overall } \\
\text { means* }\end{array}$} \\
\hline & Charollais & Dorset & Texel & Male & Female & Single & Twin & \\
\hline$n$ & 14 & 15 & 16 & 20 & 25 & 21 & 24 & \\
\hline Shoulder & $2.0 \pm 0.08^{a}$ & $2.2 \pm 0.09 a$ & $2.1 \pm 0.08^{a}$ & $2.2 \pm 0.07^{a}$ & $1.9 \pm 0.06^{b}$ & $2.1 \pm 0.07^{a}$ & $2.0 \pm 0.06^{a}$ & $2.1 \pm 0.3$ \\
\hline Chest- belly & $1.4 \pm 0.08^{a}$ & $1.5 \pm 0.10^{\mathrm{a}}$ & $1.4 \pm 0.09 \mathrm{a}$ & $1.5 \pm 0.07 a$ & $1.4 \pm 0.06^{a}$ & $1.5 \pm 0.07^{a}$ & $1.4 \pm 0.06^{a}$ & $1.4 \pm 0.2$ \\
\hline Anterior-loin & $0.7 \pm 0.03^{a}$ & $0.7 \pm 0.03^{a}$ & $0.6 \pm 0.03 a$ & $0.7 \pm 0.03 a$ & $0.6 \pm 0.03 b$ & $0.7 \pm 0.03^{a}$ & $0.7 \pm 0.03^{a}$ & $0.7 \pm 0.1$ \\
\hline Leg & $3.8 \pm 0.2^{\mathrm{a}}$ & $4.2 \pm 0.4^{a}$ & $4.0 \pm 0.3^{a}$ & $4.1 \pm 0.2^{a}$ & $3.9 \pm 0.2^{\mathrm{a}}$ & $4.0 \pm 0.2^{\mathrm{a}}$ & $4.0 \pm 0.2^{\mathrm{a}}$ & $4.0 \pm 0.6$ \\
\hline Neck & $1.0 \pm 0.1^{\mathrm{a}}$ & $1.2 \pm 0.1^{\mathrm{a}}$ & $1.1 \pm 0.1^{a}$ & $1.1 \pm 0.1^{a}$ & $1.1 \pm 0.1^{a}$ & $1.1 \pm 0.1^{\mathrm{a}}$ & $1.1 \pm 0.1^{a}$ & $1.1 \pm 0.2$ \\
\hline Rear-loin & $3.0 \pm 0.1^{\mathrm{a}}$ & $3.1 \pm 0.2^{\mathrm{a}}$ & $2.8 \pm 0.2^{\mathrm{a}}$ & $3.0 \pm 0.1^{\mathrm{a}}$ & $3.0 \pm 0.1^{\mathrm{a}}$ & $3.1 \pm 0.1^{\mathrm{a}}$ & $2.9 \pm 0.1 \mathrm{a}$ & $3.0 \pm 0.5$ \\
\hline
\end{tabular}

ab Different literals in the same row, within subclass, indicate differences $(P<0.05)$. ${ }^{*} \pm$ standard deviation.

Cuadro 4. Medias de cuadrados mínimos (media \pm error estándar) de los porcentajes de cortes primarios de la media canal izquierda, según raza paterna, sexo, y tipo de nacimiento del cordero

Table 4. Least-squares means (mean \pm standard error) of percentages of major cuts of the left half carcass, according to sire breed, lamb sex, and lamb birth type

\begin{tabular}{|c|c|c|c|c|c|c|c|c|}
\hline \multirow[t]{2}{*}{ Variable } & \multicolumn{3}{|c|}{ Sire breed } & \multicolumn{2}{|c|}{ Lamb sex } & \multicolumn{2}{|c|}{ Lamb birth type } & \multirow{2}{*}{$\begin{array}{l}\text { Overall } \\
\text { means* }\end{array}$} \\
\hline & Charollais & Dorset & Texel & Male & Female & Single & Twin & \\
\hline$n$ & 14 & 15 & 16 & 20 & 25 & 21 & 24 & \\
\hline Shoulder & $16.8 \pm 0.4^{a}$ & $17.1 \pm 0.6^{a}$ & $17.1 \pm 0.5^{a}$ & $17.4 \pm 0.3^{a}$ & $16.6 \pm 0.3^{b}$ & $16.9 \pm 0.3^{a}$ & $17.0 \pm 0.3^{a}$ & $17.0 \pm 1.1$ \\
\hline Chest-belly & $12.0 \pm 0.3^{a}$ & $11.7 \pm 0.2^{\mathrm{a}}$ & $11.6 \pm 0.2^{a}$ & $11.9 \pm 0.2^{\mathrm{a}}$ & $11.7 \pm 0.2^{\mathrm{a}}$ & $11.8 \pm 0.2^{a}$ & $11.7 \pm 0.2^{\mathrm{a}}$ & $11.7 \pm 0.9$ \\
\hline Anterior-loin & $5.8 \pm 0.2^{\mathrm{a}}$ & $5.4 \pm 0.3^{a}$ & $5.4 \pm 0.3^{a}$ & $5.9 \pm 0.2^{\mathrm{a}}$ & $5.2 \pm 0.2^{b}$ & $5.5 \pm 0.2^{\mathrm{a}}$ & $5.5 \pm 0.2^{a}$ & $5.5 \pm 0.6$ \\
\hline Leg & $31.8 \pm 2.1 \mathrm{a}$ & $32.6 \pm 3.3^{a}$ & $33.0 \pm 2.8 \mathrm{a}$ & $30.8 \pm 1.6^{a}$ & $34.1 \pm 1.6 \mathrm{~b}$ & $32.1 \pm 1.6^{a}$ & $32.8 \pm 1.6^{a}$ & $32.5 \pm 2.2$ \\
\hline Neck & $8.6 \pm 0.2^{a}$ & $9.1 \pm 0.2^{a}$ & $9.4 \pm 0.2^{\mathrm{a}}$ & $9.0 \pm 0.2^{a}$ & $9.1 \pm 0.2^{\mathrm{a}}$ & $9.1 \pm 0.2^{a}$ & $8.9 \pm 0.2^{a}$ & $9.0 \pm 0.8$ \\
\hline Rear-loin & $25.0 \pm 0.4^{a}$ & $24.0 \pm 0.4^{a}$ & $23.6 \pm 0.4 a$ & $23.7 \pm 0.3^{a}$ & $24.7 \pm 0.3^{b}$ & $24.6 \pm 0.3^{a}$ & $23.8 \pm 0.3^{a}$ & $24.2 \pm 1.7$ \\
\hline
\end{tabular}

ab Different literals in the same row, within subclass, indicate differences $(P<0.05)$. ${ }^{*}: \pm$ standard deviation.

a edades adultas(26). Estos mismos autores encontraron que la circunferencia de la pierna también puede ser afectada por el tipo de nacimiento, pues ya que corderos de la raza iraní Makuie, tuvieron valores más altos de este parámetro $(\mathrm{P} \leq 0.05)$ en corderos de parto sencillo que en los de parto doble y triple. La relevancia del tamaño en la pierna estriba en que esa pieza es considerada como un corte de primera, con un alto valor económico, que si además tiene una amplia circunferencia, puede mejorar la calidad de la canal, debido que a que los sistemas de percentage values in the leg and rear-loin $(P \leq 0.01)$. These results contrast with studies that evaluated Jezersko-solèava $x$ Romanov crossbred lambs(28), Segureña lambs(29) as well as pure Corriedale lambs and crosses $(30)$ where the sex did not influence any of these variables. This may be due to differences in the weight and age at slaughter of lambs in different works, because males getting closer to mature weight have higher percentage of muscle and bone than females, while these have more fat accumulating in the rump, abdomen and $\operatorname{leg}(28,29)$. 
clasificación valoran mejor las canales con piernas redondeadas y perfiles convexos.

Composición regional de la canal

Aunque algunos estudios muestran un efecto directo $(P \leq 0.05)$ de genotipo sobre la composición regional de la canal $(27,28)$, en el presente trabajo no se encontró un efecto $(P \geq 0.05)$ debido a raza paterna, tanto en los valores absolutos como relativos de las piezas de la canal. Respecto al efecto del sexo, los Cuadros 3 y 4 muestran que los machos superaron a las hembras $(P \leq 0.05)$ en el peso y porcentajes de la espaldilla y del badal, pero las hembras presentaron mayores valores en los porcentajes de la pierna y del lomo posterior $(P \leq 0.01)$, lo que contrasta con estudios que evaluaron corderos cruzados J ezersko-solèava x Romanov(28), corderos raza Segureña(29), así como corderos Corriedale puros y cruzados(30) donde el sexo no tuvo influencia en ninguna de estas variables, lo cual puede deberse a diferencias en el peso y edad de sacrifico de los corderos en los diferentes trabajos, ya que al acercarse más al peso maduro los machos presentan mayor porcentaje de músculo y hueso que las hembras, mientras que éstas tienen más grasa que acumulan en lugares como la grupa, el abdomen y la pierna $(28,29)$.

En la proporción de pierna se obtuvo una interacción $(P \leq 0.01)$ entre la raza paterna y el sexo del cordero (Figura 4). No se observaron diferencias $(P \geq 0.05)$ entre los tres grupos de hembras; sin embargo, entre los machos, los hijos de padres Dorset y Texel tuvieron mayores porcentajes de la pierna $(P \leq 0.01)$ que los hijos de padres Charollais, quienes tuvieron el porcentaje más bajo $(27.0 \pm 2.2 \%)$ entre los tres grupos de machos. Lo anterior puede atribuirse principalmente a la superioridad que tuvieron las hembras sobre los machos en el porcentaje de la pierna (Cuadro 4).

\section{CONCLUSIONES E IMPLICACIONES}

Los tres cruzamientos representan una buena opción para ser empleados en los sistemas de
In the proportion of leg, there was an interaction $(P \leq 0.01)$ between sire breed and sex of lamb (Figure 4). There were no differences $(P \geq 0.05)$ among the three female groups. However, among males, Dorset and Texel sired-lambs had higher percentages of the leg $(P \leq 0.01)$ than Charollais-sired lambs, who had lower percentage $(27.0 \pm 2.2 \%)$ among the three male groups. This can be attributed mainly to the superiority of females over males in the leg percentage (Table 4).

\section{CONCLUSIONS AND IMPLICATIONS}

The three crosses represent a good choice to be employed in these production systems because they have similar values in the majority of meat traits. However, the Charollais-sired lambs had a higher rib eye area, which associated with a greater amount of muscle in the carcass, can be a good comparative advantage. Males had higher slaughter and carcass weights than females, as well as the size of certain body pieces, but there were no differences attributed to sex in the carcass yield, rib eye area or subcutaneous fat thickness. It

Figura 4. Efecto de la interacción raza paterna x sexo del cordero en el porcentaje de la pierna

Figure 4. Effect of the interaction between paternal breed $x$ sex of the lamb in the percentage of the leg

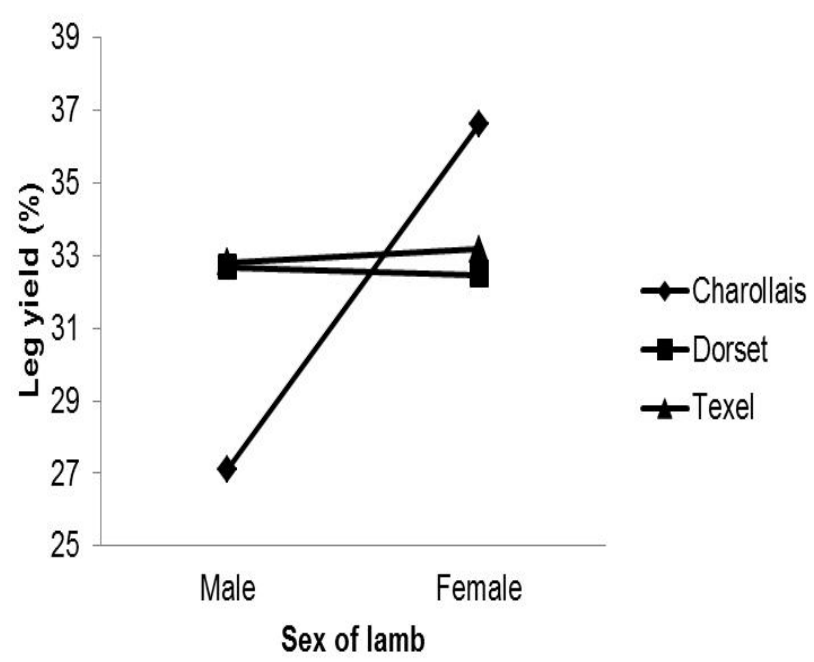


producción ovina de Hidalgo, porque tuvieron valores semejantes en la mayoría de los parámetros cárnicos; no obstante, los corderos hijos de padres Charollais tuvieron mayor área del ojo de chuleta, lo cual, por estar asociado a una mayor cantidad de músculo en la canal, puede ser una buena ventaja comparativa. Los machos tuvieron promedios mayores que las hembras en el peso al sacrificio y de la canal, así como en el tamaño de algunas partes del cuerpo, pero no hubo diferencias atribuidas al sexo en el rendimiento en canal, el área del ojo de chuleta ni en la cantidad de grasa subcutánea, lo cual significa que en los tres cruzamientos terminales, tanto hembras como machos pueden ser destinados al abasto, sin esperar grandes diferencias en la calidad de la canal. Los corderos nacidos de parto sencillo sólo superaron a los de parto doble en el espesor de la grasa subcutánea y la longitud de la pierna, lo cual significa que tuvieron una buena respuesta productiva en la etapa de crecimiento, pero el tipo de nacimiento sí influyó en su finalización. Es necesario efectuar más estudios para evaluar otras razas bajo diferentes sistemas de producción, hacer estudios de composición tisular y calidad de la carne, evaluar características de supervivencia, reproductivas y sanitarias, e incluir más animales en las pruebas, con el propósito de disponer de una información suficiente, clara y convincente que esté en condiciones de recomendarse a los productores de ovinos en Hidalgo.

\section{AGRADECIMIENTOS}

Se agradece el financiamiento del Proyecto (CONACYT-FOMIX Clave 151194): “Evaluación de sistemas de producción integrales de carne de cordero en diferentes zonas productoras de ovinos en el Estado de Hidalgo".

\section{LITERATURA CITADA}

1. SIAP-SAGARPA. Servicio de Información Agroalimentaria y Pesquera. Resumen Nacional Ovinos. Producción, precio, means that in the three terminal crosses both females and males can be earmarked to the supply, with similar carcass quality. Single lambs only outperformed twins in the subcutaneous fat thickness and leg length, which means that they had a good productive response at the growth stage, but the type of birth had an influence at the finishing stage. It is necessary to conduct more studies to evaluate other breeds under different production systems, studies of tissue composition and meat quality, assess survival, reproductive and health characteristics, and include more animals in testing, in order to have a sufficient, clear and convincing information for sheep producers in Hidalgo.

\section{ACKNOWLEDGMENTS}

Grateful for the financing of the project CONACYT-FOMIX key 151194: "Evaluation of integrated production systems of lamb in different sheep-producing areas in the State of Hidalgo".

\section{End of english version}

valor, animales sacrificados y peso de carne en canal. http:/ /www.siap.gob.mx/resumen-nacional-pecuario/. Consultado: Jul 15, 2014.

2. Arteaga CJD. Diagnóstico actual de la situación de los ovinos en México. En: Gutiérrez YA. Congreso Mundial de la Lana y el Cordero. Santiago de Querétaro, Qro. México. 2007.

3. Lara PJ. Utilización de cruzamientos en la producción ovina. Primer Simposio Internacional de Ovinos de Carne. Pachuca, Hidalgo. 2003:63-69.

4. Dickerson GE, Glimp HA, Gregory KE. Genetic resources for efficient meat production in sheep: preweaning viability and growth of Finnsheep and domestic crossbred lambs. J Anim Sci 1975; 41:43-53.

5. De la Cruz $C L$, Torres HG, Núñez DR, Becerril PCM. Evaluación de características productivas de corderos Hampshire, Dorset y Suffolk en pruebas de comportamiento en Hidalgo, México. Agrociencia 2006;40:59-69.

6. Mata EA. Evaluación de tres razas ovinas paternas en el comportamiento productivo de corderos del nacimiento al peso de sacrificio [tesis maestría]. Montecillo, Texcoco, Edo. de México: Colegio de Postgraduados; 2013.

7. INEGI. Instituto Nacional de Estadística y Geografía. www.hidalgo.gob. $m x / p=512$. Consultado: Jul 15, 2014. 


\section{CARACTERÍSTICAS DE LA CANAL DE CORDEROS PARA CARNE EN HIDALGO, MÉXICO}

8. Colomer Rocher F, Morand Fehr P, Kirton AH, Delfa R, Sierra Alfranca I. Métodos normalizados para el estudio de los caracteres cuantitativos y cualitativos de las canales caprinas y ovinas. Cuadernos INIA 1988; 17:11-32.

9. SAS. SAS User's Guide; Versión 9.0: SAS Institute Inc. Cary, NC (USA). 2002.

10. Steel RGD, Torrie JH. Principles and procedures of statistics: A biometrical approach. $2^{\text {nd }}$ ed. New York, USA: McGrawHill Book Co.; 1980.

11. Ceñeque C, Sañudo C. Estandarización de las metodologías para evaluar la calidad del producto (animal vivo, canal, carne y grasa) en los rumiantes. Madrid, España: Monografías INIA. Serie Ganadera No. 3; 2005.

12. Momani SM, Abdullah A, Kridli RT, Blaha J, Sáda L, Sovják $R$. Fattening performance and carcass value of Awassi ram lambs, $\mathrm{F} 1$ crossbreds of Romanov $x$ Awassi and Charollais $x$ Awassi in Jordan. Czech J Anim Sci 2002; 10:429-438.

13. Vázquez SET, Partida PJA, Rubio LM, Méndez MD. Comportamiento productivo y características de la canal en corderos provenientes de la cruza de ovejas Katahdin con machos de cuatro razas cárnicas especializadas. Rev Mex Cienc Pecu 2011;2(3):247-258.

14. Leymaster KA, Jenkins TG. Comparison of Texel and Suffolksired crossbred lambs for survival, growth, and compositional traits. J Anim Sci 1993; 71:859-869.

15. Bores QR, Velázquez MA, Heredia A. Evaluación de razas terminales en esquemas de cruza comercial con ovejas de pelo F1. Téc Pecu Méx 2002;40:71-79.

16. Partida PJA, Braña D, Martínez L. Desempeño productivo y propiedades de la canal en ovinos Pelibuey y sus cruzas con Suffolk y Dorset. Téc Pecu Méx 2009; 47:313-322.

17. Martínez AA, Bores QR, Velázquez MA, Castellanos RA. Influencia de la castración y del nivel energético de la dieta sobre el crecimiento y composición corporal del borrego Pelibuey. Téc Pecu Méx 1990;28(3):125-132.

18. Hancock SN, Oliver MH, McLean C, Jaquiery AL, Bloomfield $\mathrm{FH}$. Size at birth and adult fat mass in twin sheep are determined in early gestation. J Physiol 2012;590(5):12731285.

19. Milerski M, Margetin M, Maxa J. Factors affecting the longissimus dorsi muscle depth and backfat thickness measured by ultrasound technique in lambs. Arch Tierz Dummerstorf 2006;49:282-288.
20. Cemal I, Karaca O, Altin T, Godkal O, Yilmaz M, Yilmaz O. Ultrasound measurements of eye muscle properties and backfat thickness in Kivircik lambs. J Biol Sci 2007; 7(1):8994.

21. Osorio JC, de Oliveira NM, Nunes AP, Pouey JL. Meat production in sheep of five genotypes. 3. Losses and morphology. Ciência Rural, Santa Maria 1996;26:477-481.

22. Torrescano UGR, Sánchez EA, Peñúñuri MFJ, Velázquez CJ, Sierra RT. Características de la canal y calidad de la carne de ovinos Pelibuey engordados en Hermosillo, Sonora. Biotecnia 2009; XI(1):40-50.

23. Teixeira A, Cadavez V, Delfa R, Bueno MS. Carcass conformation and joints composition of Churra Galega Bragançana and crossbred lambs by Suffolk and Merino precoce sire breeds. Spanish J Agric Res 2004;2(2):217225.

24. Camacho A, Capote J, Mata J, Argüello A, Viera J J, Bermejo LA. Effect of breed (wool and hair) and sex on the carcass quality of suckling lambs under intensive management. R Bras Zootec 2013;42(12):892-898.

25. Qureshi MA, Khan MA, Mohi-Udin G, Ahmed MK, Rehwan A. Genetic studies on Awassi sheep in Pakistan: Birth weight and weaning weight. Pakistan J Agric Res 1991;12:298302.

26. Jafari S, Hashemi A. Estimation of genetic parameters for body measurements and their association with yearling liveweight in the Makuie sheep breed. S Afr J Anim Sci 2014;44(2): 140-147.

27. Miguélez E, Zumalacárregui J M, Osorio MT, Beteta O, Mateo J. Carcass characteristics of suckling lambs protected by the PGI "Lechazo de Castilla y León" European quality label: effect of breed, sex and carcass weight. Meat Sci 2006; 73:82-89.

28. Žgur S, Cividini A, Kompan D, Birtiè D. The effect of live weight at slaughter on lambs carcass traits and meat characteristics. Agric Conspec Sci 2003;68(3):155-159.

29. Peña F, Cano T, Domenech V, Alcalde Ma J, Martos J, GarcíaMartínez A, Herrera M, Rodero E. Influence of sex, slaughter weight and carcass weight on "non-carcass" and carcass quality in Segureña lambs. Small Ruminant Res 2005;60:247254.

30. Bianchi G, Garibotto G, Feed O, Betancur O, Franco J. Efecto del peso al sacrificio sobre la calidad de la canal y de la carne de corderos Corriedale puros y cruza. Arch Med Vet 2006;38(2):161-165. 
